\title{
A Probe into the Cultivation Model of the Undergraduate Business English Major in Universities under the Background of Guangdong-Hong Kong-Macao Greater Bay Area
}

\author{
Haining Huang ${ }^{\text {a,* }}$, Xihua Chen, Yuanmei Fang \\ Guangzhou College of Technology and Business, Guangzhou 510850, China \\ astrongerEagle@126.com \\ *Corresponding author
}

Keywords: Guangdong-Hong Kong-Macao Greater Bay Area; Business English; Innovate; the Cultivation Model; Construction of Teachers' Team; Cooperative Education

\begin{abstract}
Guangdong-Hong Kong-Macao Greater Bay Area is one of the regions with the highest degree of openness and strongest economic vitality in China. The universities in the Bay Area bear the heavy responsibility of cultivating innovative and applied talents in the new era. However, the colleges and universities have unclear goals in the training of business English professionals, the positioning is not clear; the lack of flexibility and diversity in the curriculum; the lack of training channels, weak teacher resources, etc.; the lack of innovation and application skills in talent training, cannot adapt Bay Area Economic Development. Based on the development plan of Guangdong-Hong Kong-Macao Greater Bay Area, colleges and universities should start from the social needs and business English professional characteristics, re-examine the talent training objectives, attach importance to quality training, highlight the characteristics of internationalization, compound and application; adjust the curriculum and cultivate interdisciplinary, Multi-disciplinary composite business English skill-based talents; attach importance to the "double-skilled" teacher training, improve the practical teaching ability of the teaching staff, lay emphasis on collaborative education and cultivate innovative and entrepreneurial talents; thereby promoting talent innovation, technological innovation and industrial innovation in Bay Area, opening up new models for business English professional training mode Explore ideas.
\end{abstract}

\section{Introduction}

Guangdong, Hong Kong and Macao have become a window for China`s foreign exchanges and development. The Bay Area is composed of two special administrative regions and nine cities in Guangdong, which are the most open and economically dynamic regions in China. Guangdong-Hong Kong-Macao Greater Bay Area is very special in both political and economic terms. Although the cities in the Bay Area are the same as in China, they contain two political systems and three customs zones, and their coordinated development requires strategic wisdom. Therefore, the high-speed economic growth in the Greater Bay Area not only needs to expand the international market, but also needs to train a large number of innovative thinking and awareness of the composite, applied, skilled business English talent. The colleges and universities in the Bay Area shoulder the heavy responsibility of cultivating the new generation of China, and no longer train a single business English major with the ability to hear and write, but also need to train people with knowledge background in English, business, law, economy, management and other disciplines. Under this circumstance, how to innovate the training mode of business English professionals and train new types of business English talents suitable for the needs of the new era and social development is an unavoidable topic in the Bay Area.

\section{The Current Situation of the Training Mode of Business English Professionals}

The Ministry of Education has established business English undergraduate major for more than 
ten years. In the Bay Area, most of the undergraduate institutions have set up business English majors. By consulting the official websites of 61 undergraduate colleges and universities among Guangdong Province, there are fewer than ten universities that have not constructed with business English majors, and there are many commonalities in the training goals, training requirements, implementation methods and core curriculum of other colleges and universities. However, it can be seen that some weakness in the application-oriented talent training model, which is not innovative enough. This is reflected in the following three points.

\subsection{Vagueness in the Training Goals and the Positioning}

Although many undergraduate colleges and universities in the Bay Area have accumulated a lot of successful experience in the business English professional training, it is still facing some difficulties in talents` training because the construction of Guangdong, Hong Kong and Macao Bay Area is not long. At this stage, business English talents are required with distinct characteristics of the times, professional requirements. Many colleges and universities have not yet combined with the national standard and the need of construction of the Greater Bay Area so that to redefine the training of talents, do some research on the development of training program, be more specific. If colleges and universities cannot consider those things well, they may fail to fully predict the practical difficulties faced by the graduates of the major. In general, business English majors lack scientific and rational and targeted programs in terms of talent training goals and positioning, and the reform and innovation of talent training has not kept pace with the development of education in the new era.

\subsection{Lack of Flexibility and Diversity in Curriculum}

According to the research, the business English curriculum is based on the "English basic knowledge and business English knowledge" model, has not yet transitioned from "knowledge-based education" to "human-center education" model, ignoring the importance of learning business English needs to reasonably integrate interdisciplinary professional resources. The results show that the curriculum is relatively fixed, single, the curriculum system is not strong comprehensive, the practice of less time and other issues are more prominent, indicating that the business English curriculum is still not well matched with social needs, the curriculum system needs to be perfected. For example, Guangzhou College of Technology and Business has set up business English major since 2015. It has designed some core courses which are mainly integrated English, comprehensive business English, business English translation, international trade practice English, etc. From this point of view, the degree of interdisciplinary integration of resources is low that comprehensive English curriculum is designed for two years and integrated business English would be given to students in the third year. The curriculum is relatively fixed and lack of diversity and the practical teaching process arrangement of ten lessons, not enough to make classroom learning and practice closely integrated.

\subsection{Lack of Training Channels and Professional Teachers}

Educational informatization requires more and more language training rooms and practical teaching equipment, but many colleges and universities have seriously inadequate investment in practical training room construction, practice base construction, practical teaching equipment and so on. The opening and utilization rate of the language training room is not high, the construction of the practice base is not perfect, the practical teaching equipment is relatively old, which seriously affects the teaching and learning effect. In the formulation of practical training plan, the relevant teachers sloppy to cope with, flow in the form, the content of practical training is not specific enough and does not address the needs of employers and the combination of macro-situation, therefore, students cannot achieve the purpose of practical training. According to research, most business English professional teachers lack of business knowledge background or lack of experience in working in enterprises or industries so as to participate in top-level practice. Due to less practice, some teachers only have a weak knowledge structure and teachers' academic qualifications, titles, professional direction structure is not reasonable. So, it is the urgent need for 
cross-disciplinary leaders and industry skilled craftsmen.

Based on the above problems in the training of business English professionals in colleges and universities in the Bay Area, it is necessary for colleges and universities to start from the perspective of the actual needs of society, to revise the training program of business English professionals by re-examining the goal of personnel training, adjusting curriculum, expanding the training path, strengthening the construction of teachers' team, etc. Cultivate multi-disciplinary, multi-disciplinary composite business English talents to promote the sustained and stable development of Guangdong, Hong Kong and Macao.

\section{Innovative Business English Professional Training Mode Ideas}

The strategy of Guangdong-Hong Kong-Macao Greater Bay Area likes the wings for the development of China's economy, culture. The National Standard for the Teaching Quality of Undergraduate in Business English in Higher Education (here in after referred to as the "Business English Standard") clearly states that the business English major aims to cultivate the basic skills of English, has an international vision and humanistic qualities, and masters the basic theories and knowledge of linguistics, economics, management, law (international commercial law); to be familiar with the general rules and practices of international business, have the ability of English application, business practice ability, cross-cultural communication ability, thinking and innovation ability, independent learning ability. After graduation, students can engage in international business work of complex, applied talents ${ }^{[1]}$. From this point of view, business English professional training should be a comprehensive, multi-level, multi-angle, interdisciplinary knowledge learning process.

\subsection{Talent Training Objectives: Pay Attention to Quality Training, Highlighting International, Complex and Applied Characteristics}

The Business English Standard has a clear description of the qualities and abilities required for business English professionals, which together constitute the content of talent training. Its interdisciplinary attributes determine that the characteristics of talent training are internationalization and compound. Before formulating the talent training program, colleges and universities should fully investigate the talent demand of enterprises in the Bay Area, keep up with the requirements of the times, and focus on solving the problem of how to teach students the ability to use business discourse skillfully. Business discourse is not the same as the language system itself, not only refers to language knowledge, such as vocabulary, grammar system, but also emphasizes the accurate use of oral or written language in the context of business, which is the unique communicative attribute of business discourse. Therefore, in the lower grade stage, it is necessary to make clear that business discourse is the teaching goal, pay attention to practice listening and writing skills in the business context, and cultivate students' ability to use English for self-expression. In the senior year, colleges and universities should create conditions for students to engage in international business activities through systematic teaching, simulation training, social practice and internship, and improve their practical ability of business negotiation, writing and translation.

Under the strategic guidance of Guangdong, Hong Kong and Macao, universities in the Greater Bay Area can determine training objectives and set up specialty according to the regional characteristics, traditions, discipline characteristics and advantages of the schools. It is important for colleges to give priority position for quality training, highlighting ingress with international, complex and applied characteristics. For example, Financial institutions can set up international finance, international trade, financial management, international accounting and other training directions; Political and Legal colleges can open foreign-related business law training direction; Teacher-training colleges can set up business English teacher education, international education management training direction; Science and Engineering colleges can open international engineering project management, international project bidding training direction; Agricultural and Forestry colleges can open agricultural trade, agriculture-related business management training direction; Tourism colleges can open foreign-related tourism management training direction; Art 
institutions can set up international cultural management, overseas art finance training direction. In a word, talent development needs sustainable development, not only in line with the positioning of schools and professional construction, but also to help students better employment and development ${ }^{[2]}$.

Taking the international business management direction of business English major as an example, the specialty consists of three skill modules: English language ability, business operation ability and computer application technology, which mainly cultivate the basic theoretical knowledge and professional knowledge necessary for business English major. Also, to cultivate skilled in English listening, speaking, reading, writing, translation and other language skills, students are training with cross-cultural business communication skills and international vision. By this way, they can master the business operation of knowledge and skills, engage in business management and project planning work of high-level applied talent. To ensure that students can be qualified after graduation in the Guangdong, Hong Kong and Macao Large Bay Area enterprises, can be proficient in the use of English, business management and computer knowledge engaged in international business management and planning.

\subsection{Curriculum: Interdisciplinary, Practice-Oriented, Training Complex, Applied, Skilled Personnel}

As can be seen from the training objectives of Business English Standard, business English teaching has dual objectives: (1) to teach students English in international business background; (2) to teach students to engage in international business in English. Students need to combine business knowledge with English subject knowledge, and through knowledge internalization, the two will be integrated organically. Therefore, in the formulation, adjustment and optimization of talent training programs, in addition to setting up English subjects and business knowledge and skills module courses, but also to set up cross-cultural communication and humanities and other courses, in order to meet the goal of talent training.

Business English covers economics, management, law, finance, trade and other disciplines, the application of many scenarios, strong application, therefore, teaching cannot ignore the practice. The practice session includes practical training, practice, and internship ${ }^{[3]}$. Professional practical training can practice the process in business cooperation in the business training room and other simulation teaching platform, professional practice can improve students' oral English expression ability in the second classroom activities and other environments, professional practice can use the school-enterprise cooperative practice base ${ }^{[4]}$, under the guidance of the teachers inside and outside the school to exercise students' ability to engage in business work ${ }^{[5]}$. In addition, colleges and universities can offer examination and guidance elective courses to encourage students to obtain vocational qualification certificates such as accounting, human resources management, justice or participate in innovative entrepreneurship training, through a series of practical teaching and training, students will be trained as composite, applied, skilled personnel, improve their employment competitiveness ${ }^{[6]}$.

In 2018, the Ministry of Education proposed to vigorously develop new Humanities and optimize the professional structure of disciplines. Colleges and universities should adjust and optimize some core courses according to the characteristics of the school-based curriculum and the special requirements of Guangdong, Hong Kong, Macao and The Greater Bay Area enterprises for international business management personnel, with a view to systematically cultivating students' core employability. For example, the business English major international business management direction involves legal finance, international accounting, business management, international trade, project management and another knowledge. In the new mode of talent training, we should pay special attention to the training of students' practical ability, to improve students' cross-cultural business communication and interdisciplinary business application ability, to emphasize the deep integration of professional knowledge with other disciplines, to cultivate students' vocational skills. Colleges and universities should actively turn them into new Humanities majors and adjust and optimize their courses in a timely manner. 
For example, cross-border e-commerce jobs in the Greater Bay Area of Guangdong, Hong Kong and Macao require business English students to have knowledge of law, international relations, engineering technology, international trade, finance, culture and politics, and in the new mode of talent training, business English courses should be divided into theoretical and practical courses, so that students can learn their professional knowledge. At the same time, do a good job of targeted practical training, pay attention to the training of students' professional ability are also important. Under the premise that the original language ability development objectives of students from the first semester to the fourth semester remain unchanged, the curriculum of similar majors, such as economics and law courses, will be added, with a view to meeting the standards of employers and making students more competitive. Furthermore, in the seventh semester of students, to the post capacity requirements-oriented, adjust and optimize the curriculum, such as the first 12 weeks in the school to complete the senior professional course study, the next five weeks through the school-enterprise cooperative unit to transport students to the enterprise to train comprehensive professional ability, to achieve professional internship and employment closely integrated school-enterprise cooperation model. In addition, the school can adjust and optimize some core courses according to the characteristics of the school-based curriculum and the special requirements of the enterprises of Guangdong, Hong Kong, Macao and The Greater Bay Area for business English talents, with a view to systematically cultivating students' core employment ability. It is worth mentioning that colleges and universities in the Bay Area can train more "double teachers" who meet the requirements of new era education through "please come in" and "send it out" to improve the professional ability and post practice ability of teachers in order to better serve the training of applied talents.

\subsection{Teacher System: Strengthening the Construction of Teachers` Team and Improving the Practical Teaching Ability}

To train first-class talents, it should not only have clear and feasible training objectives, scientific and reasonable training plans, but also a group of first-class teaching skills and skilled craftsmen. The quality of talent training and the professional ability of teachers are closely related to the level of business. According to the characteristics of business English professional compound and application type, business English teachers are required to master the ability and method of teaching using modern educational technology techniques in addition to the professional norms, basic skills, professional knowledge, teaching ability and practical ability of English teachers. Therefore, to strengthen the construction of business English teachers in universities in the Greater Bay Area, and improve teachers' professional ism, we can grasp the following four points under the guidance of strategy.

First, teacher training is carried out on a regular and systematic basis. Through the establishment of business English teaching and research room, the organization of qualified and academic interests of teachers out of the exchange of learning, further study related business courses. Second, encourage young teachers to learn management expertise on the job and enrich their own knowledge system. The school has also introduced a series of policies to encourage teachers to obtain the latest dynamic information on social development needs through on-the-job learning and vacation to the top job practice of enterprises, and to apply the knowledge learned to the specific process of talent training. Third, encourage teachers to innovate teaching methods and explore teaching methods that can deal with English language learning as well as teach professional content learning. By organizing teachers to learn the works and research results of classical teaching methods at home and abroad, so that they can master the principles and teaching steps of various teaching methods. Fourth, teachers are encouraged to use modern educational information technology to carry out off-line teaching, such as building quality courses, recording micro-classes, carrying out classes, flipping classes, sub-classes and other teaching methods. Through the use of a variety of information-based means to facilitate students' learning, improve the effectiveness and relevance of business English teaching. 


\subsection{Synergy: Promoting the Cultivation of Innovative and Entrepreneurial Talents}

Under the background of Guangdong, Hong Kong and Macao, the training mode for business English requires professional teachers and counselors to work together to educate people. Professional teachers need to integrate innovative entrepreneurship education into the teaching of professional courses, enrich students' knowledge reserves, expand their thinking horizons, improve their professional skills, and cultivate their innovative spirit and entrepreneurial consciousness. In the process of ideological and political education, counselors cultivate students' innovative thinking and entrepreneurial consciousness, establish a correct view of employment and career choice, and enhance their ability to resist pressure and frustration. Through collaborative education, so that students become a new era of comprehensive application ability and innovative spirit of talent.

Educating people is a dynamic long-term project, Guangdong, Hong Kong and Macao in the context of the large bay area of the evaluation of the model of education cannot be separated from the university, the government, enterprises three joint assessment. Colleges and universities should focus on the deep cooperation of industry, research and development, strive for and build a bridge of communication with various innovative enterprises, set up a special enterprise talent training base, and provide educational support for the needs of existing business English talents. The Human Resources and Social Security Bureau or the Employment Guidance Office of the three places can follow up the information on the flow of talents in real time, and the scientific research institutions and institutions of higher learning in the three places can jointly explore joint running or teacher training, set up a business English teaching and research team, create a cooperative atmosphere, and gradually improve the training model for mature talents. All in all, "send out" and "stay" is the Guangdong, Hong Kong and Macao Big Bay Area university innovative talent training model.

\section{Conclusion}

The strategy of "Guangdong, Hong Kong and Macao Bay Area” can promote the reform and exploration of the training mode of business English professionals. In this way, the innovation of talent training mode also needs to follow the laws of education and adapt to the requirements of the times. Colleges and universities should combine their own development needs and strive to create a training path that not only develops characteristics, but also conforms to the national medium- and long-term educational reform and development. Based on the innovation of training mode, the construction and assessment of teachers' team, teaching material planning and design, practical teaching and management, teaching assessment and feedback still need to be further explored and studied.

\section{Acknowledgements}

This paper is funded by Foshan social science planning project in 2020 (2020-GJ027) and the quality engineering project of Guangzhou College of Technology and Business in 2018 (NO. ZL20181113).

\section{References}

[1] Wang Lifei, Ye Xingguo, Yan Ming. The Interpretation of the National Standard Stories for Undergraduate Teaching Quality in Business English [J]. Foreign Language Teaching and Research, p297-302, 2015.

[2] Wang Zhuo, Tao Ke. Exploration of the Training Mode of Business English Professionals under the Strategic Background of "The Belt and the Road" [J]. Journal of Heilongjiang Institute of Technology, p118-122, 2017.

[3] Zeng Xuemei. Research on the Reform of the Training Model of Innovative Entrepreneurial Talents Based on the Cooperation of Production and Learning-taking Business English Major as an Example [J]. Education Modernization, p9-10, 2018. 
[4] Wen Qiufang. “Belt and Road” Language Talents` Training [J]. Language Strategy Research, p26-31, 2016.

[5] Wu Lianghui. How to Seek a Breakthrough with the Cooperation of University-enterprise Seeking Business English Teaching in Colleges and Universities [J]. Six-pan Water Normal College Journal, p101-104, 2018.

[6] Zhou You. Study on the Transformation and Upgrading of Chaozhou Ceramic Industry under the Background of Internet Finance [J]. Wuhan Business School Journal, p42-45, 2018. 